Published in: Journal for the Scientific Study of Religion (2017) 56(4):820-835

https://doi.org/10.1111/jssr.12484

\title{
Institutionalized Norms, Practical Organizational Activity, and Loose Coupling: Inclusive Congregations' Responses to Homosexuality
}

Congregations vary widely in their responses to homosexuality. Prior research tends to focus on determining which congregations are most likely to be inclusive of lesbians and gays. One puzzle still remains, however. Among those inclusive congregations that integrate gays and lesbians into congregational life, why do some adopt a formal organizational statement of welcoming while others do not? Drawing on the New Institutionalism and inhabited institutions literatures, this study is the first quantitative examination of the concept of "loose coupling" within religious organizations regarding homosexuality. Analyses using nationally representative congregational data (National Congregations Study) indicate that particular types of inclusive congregations are more likely to loosely couple their practical activity from their formal organizational stance. These findings suggest that inclusive religious organizations respond to myths and norms from various organizational fields and that agentic actors inhabiting the organization influence it by responding, interpreting, and making sense of those institutional norms. The analyses also indicate that loose coupling is one avenue through which particular types of religious organizations respond to the transformation of societal norms with innovation.

Keywords: Homosexuality, Congregations, Loose Coupling, New Institutionalism, Inhabited Institutions, Religious Organizations

Andrew L. Whitehead

Assistant Professor

Clemson University

Alw6@clemson.edu 
Over the last few decades a large number of studies examined the correlates predicting which congregations were less inclusive to gays and lesbians versus those that were more inclusive (Adler 2012; Becker 1999; Cadge, Day, and Wildeman 2007; Cadge, Olson, and Wildeman 2008; Djupe and Neiheisel 2008; Hartman 1996; Moon 2004; Olson and Cadge 2002; Scheitle, Merino, and Moore 2010; Whitehead 2013a, 2013b). This literature highlights the importance of local theological and political cultures, religious tradition, and various demographic attributes of each congregation. However, one question still remains: why do some congregations who report allowing gays and lesbians to participate in all aspects of congregational life (hereafter referred to as inclusive congregations) take a further step of adopting an official statement of welcoming? Put another way, why is the practical activity of some congregations not reflected in their official organizational stance? This puzzle concerns a sizeable number of congregations. A third of congregations in the US report practical activity integrating gays and lesbians into congregational life - not officially signaled by the organization.

Prior literature tends to overlook the qualitative difference between inclusive congregations that are formally welcoming to gays and lesbians and those that take no official stance but integrate gays and lesbians into congregational life nonetheless. In order to address this gap, the present study draws on New Institutionalism and the concept of loose coupling to explicate which congregations are most likely to align their practical activity and formal stance. New Institutionalism theory demonstrates how organizational myths and norms are central to an organization maintaining viability within its particular organizational field (Meyer and Rowan 1977). Such institutionalized norms arise over time, usually due to the success of certain organizations within the field. However, the reasons that certain practices are normative within 
organizational fields are lost over time. Organizations begin to maintain certain norms and myths even if they contradict the lived reality of the organization. This disconnect between organizational norms and practice is called "loose coupling" (Weick 1976). While loose coupling seems counterintuitive, it actually serves the interest of the organization. It allows the organization to project a particular stance to the organizational field of which it is a part while simultaneously allowing (or even encouraging) behavior within the organization that may contradict certain myths and norms but serves the needs of the organization at the moment.

Congregations are an ideal place to examine loose coupling and organizational myths because of their (almost exclusively) voluntary nature. Individuals come and go as they please and congregations must tread lightly around certain issues that could harm either their reputation in the wider organizational field (leading to a loss of denominational status or a stigmatized identity) or their ability to draw from potential local congregants. Congregations also straddle multiple organizational fields that may have competing norms and myths. Therefore, while inclusive congregations might integrate gays and lesbians into congregational life, only those that perceive sufficient ties to particular organizational fields might take the additional step of taking a formal organizational stance. Overall, this analysis highlights the influence of those norms present in particular organizational fields that consistently impinge upon congregations.

The following study examines this puzzle using a nationally representative sample of U.S. congregations. Multivariate analyses compare loosely coupled congregations with those signaling a tight coupling between a formal organizational stance of welcoming and day-to-day practical activity. I find that clergy demographics and congregations' political stances are predictive of which inclusive congregations exhibit loose coupling. These findings have implications for future work drawing on New Institutionalism as well as studies examining 
congregational responses to important social issues like the worldwide refugee crisis or social inequality. This analysis answers recent calls for analyzing innovation within religious organizations and focusing on the conditions that yield such outcomes (Bruce and Packard 2016). To do so it highlights how some religious congregations, during a period of dramatic change in attitudes toward homosexuality in the broader population, were able to respond to a transforming milieu while complying with the norms of their various institutional fields.

\section{New Institutionalism and Loose Coupling}

In what many consider the genesis of new institutionalism, Meyer and Rowan (1977) posit that structural similarities across organizations arise because organizations are working to conform to cultural "myths" that promote public legitimacy which is necessary for survival even if these structural traits are not necessary within each organization (Hallett 2010:53). The cultural rules incorporated by the organizations provide rationales for activity. Through conforming to these rules organizations gain legitimacy from the institutional context. It is from this context that the ideas, beliefs, and values originate that standardize organizational behavior (Greenwood and Hinings 1996; Meyer and Rowan 1977). The relationship between organizations and their environment is undeniable in new institutionalism theory: "Organizations are interpenetrated with their environments, which may constitute (rather than affect) organizational identities, structures, and activity routines" (Scott et al. 1994:32). New institutionalism proposes that an organization's survival depends on conforming to social norms as much as (or even more than) achieving high levels of production efficiency (Basu, Dirsmith, and Gupta 1999; DiMaggio and Powell 1983). Therefore, organizations assume new policies (or not) in order to signal their dedication to the norms of their institutional context thereby gaining legitimacy from the wider community. 
There are generally two avenues through which myths operate. In the first sense myths operate as widely shared idealized cultural accounts that dictate how an organization should operate (Meyer and Rowan 1977:342). Organizations gain legitimacy through these myths and they diffuse as organizations conform to them. In the second sense researchers focus on the contradictions that arise from the "macro-myths" - which provide legitimacy - and the actual practice of an organization. To minimize conflict, organizations regularly build space between the organizational adherence to the myth and their core activity (Hallett 2010). However, organizations work to conceal this gap to maintain the legitimacy that conforming to the myth brings. The tendency of organizations to maintain and simultaneously conceal the gaps between formal structure and core activity is referred to as loose coupling. It is through loose coupling that organizations integrate components proposed by cultural myths while keeping technical activities largely unaffected thereby avoiding possible conflict (Hallett and Ventresca 2006b). According to Meyer (1983; as cited in Basu, Dirsmith, and Gupta 1999), organizations decouple symbolic displays from technical work "so that the legitimating rules do not constrain practical activity and so that the exigencies of practical activity do not expose ongoing anarchy and lead to loss of legitimacy" (23).

Weick (1976:3) explained that loose coupling is akin to building blocks that can be grafted onto an organization or alternatively severed with relatively little disturbance to either the other blocks or the organization as a whole. Loose coupling allows an organization to be more sensitive to its environment. Loosely coupled systems have greater local adaptation because one system can respond while others remain unchanged. Adjustments are made without affecting the whole organization. Therefore, entire organizations are not "loosely coupled" but rather some 
aspects are tightly coupled while others are loose (Hallett and Ventresca 2006b; Orton and Weick 1990; Weick 1976).

The dynamics of loose coupling are evident in a host of settings. Schools (Hallett 2010; Meyer and Rowan 1977; Weick 1976; Young 2006), government agencies (Basu et al. 1999), work environments (Yang and Zheng 2011), and nation-states (Clark 2010; Swiss 2009) all contain systems that are loosely coupled from some portion of their practical activity. Religious organizations exhibit loose coupling, as well. The ordination of women (Chaves 1996, 1997) and family-related pastoral practice (Wilcox, Chaves, and Franz 2004) are both areas where the formal statements from the religious organization deviate from its practical activity. In all of these examples the core activity of the organization is separated from its legitimacy-gaining formal signals to the institutional environment. Concerning homosexuality, some inclusive religious congregations also work to buffer their formal stance from their practical activity.

\section{Homosexuality, Conflict, and Loose Coupling in Congregations}

Homosexuality is a contentious issue for many religious organizations. The possibility that some maintain loose coupling between their official stance and the day-to-day actions of the congregation is clear. This is even (or perhaps, especially) true for inclusive congregations. A number of ethnographic accounts of inclusive congregations provide evidence of loose coupling. For example, a congregation in Becker's (1999) study allowed a gay man to share his experiences through song during Sunday church services but resisted the idea of passing an “open and affirming” resolution (Becker 1999:115). This inclusive congregation felt that it was already widely understood that they welcomed lesbians and gays and resented the idea of a formal policy. In a separate study, a group of deacons at a Baptist church that was forced to take a stance "wished that the whole "issue of homosexuality would just go away without requiring a 
decision from us"” (Hartman 1996:33). Many congregations would rather not have to formalize a response but continue their ministry activities unchanged.

Ammerman (1997) presented a look into three congregations that were responding to the issue of homosexuality. She found the most obvious example of loose coupling in a Catholic parish. While open and affirming of gays and lesbians, it did not consider the issue to be on the public agenda of the parish. This was in spite of the fact that gays and lesbians were allowed leadership positions (Eucharistic ministers) and could participate in a parish ministry geared toward lesbians and gays. As Ammerman writes, "Both the loose structure of the parish and the freedom with which parishioners interpret their relationship to Church teachings have facilitated the ministry St. Matthew's is able to extend to gay and lesbian persons" (1997:170). The loose coupling of practical activity and the church's formal stance allow for parishioners with differing beliefs to worship together with little conflict. In this way anyone, gay or not, can become involved in the church life without having to wait for an official doctrinal rationale (Ammerman 1997:174).

In responding to homosexuality inclusive congregations are forced to grapple with the signal they send to the various organizational environments of which they are a part. Some congregations are positioned in such a way that they can maintain a tight coupling between their formal statement (or lack thereof) and the practical activity of the congregation. Therefore, certain inclusive congregations officially welcome gays and lesbians and allow for their full participation (Scheitle et al. 2010). As discussed above, however, a number of inclusive congregations refuse to adopt an official statement while simultaneously allowing participation by gays and lesbians. These congregations are conforming to the norms of their organizational environments thereby ensuring that the legitimacy afforded congregations that do not openly 
affirm homosexuality is not jeopardized. However, gays and lesbians are allowed to participate in the practical activity of the congregation. If these congregations were to make a formal statement they would be risking both internal and external conflict leading to the possible loss of members. Thus, for many inclusive congregations a lack of a formal statement must be maintained to appease the wider religious culture and those members who identify with it. At the same time they allow gays and lesbians to participate in the religious life of the congregation due to a desire to minister to this population. This helps to explain why many congregations are opposed to adopting formal statements signifying their stance on homosexuality for fear of conflict (Cadge et al. 2008; Djupe, Olson, and Gilbert 2006).

For the congregations in the Becker (1999) and Ammerman (1997) studies it was imperative that they loosely couple their openness toward gays and lesbians in the practical activity of day-to-day ministry from any formalized stance. As discussed earlier, formal statements operate as signals to the environment that work to achieve legitimacy for the organization (Meyer and Rowan 1977). However, not adopting a formal statement is also a signal. Whether or not an organization's signal takes the form of a formal statement will then depend upon the norms of the primary organizational field from which the organization seeks to draw its legitimacy. For instance, studies show that schools will adopt formal structures to signal to the wider public that they conform to the popular models of education and should receive the proper amount of legitimacy (Hallett 2010; Young 2006). For religious institutions a different type of loose coupling takes place. Denominations and congregations commonly adopt no formal stance even though the practical activity within these organizations might warrant it. For example, many denominations allow for female religious leaders at the congregational level but never formally adopt a statement allowing for such gender equality in leadership (Chaves 1997). 
Loose coupling within congregations occurs because the norm of the organizational field is to not have a formal statement. Therefore, to not have a formal statement conforms to the norms of a particular organizational environment, acts as the signal to the environment, and garners legitimacy for the organization.

However, congregations are not a part of only one organizational field. There is an overlapping of myths and norms from a variety of fields that constitute the organizational context within which inclusive congregations exist. Regarding the present puzzle, while not adopting a formal statement adheres to the norms of a particular organizational field, for some inclusive congregations adopting a statement might be ideal due to competing norms and myths prevalent in different fields. So the question remains: in what types of inclusive congregations do we find this sort of organizational innovation most prevalent? Can we predict which inclusive congregations are most likely to loosely couple compared to those whose practical activity matches their organizational stance? While prior research on congregational responses to homosexuality puts forth many convincing theories why some are more welcoming while others are not, New Institutionalism and loose coupling helps to explicate why among inclusive congregations, only some take a formal stance. New Institutionalism and the concept of loose coupling provide an organizational explanation to why many congregations that integrate gays and lesbians do not take a formal organizational stance.

\section{Inclusive Congregations and Loose Coupling}

Following the New Institutionalism and loose coupling literature a number of predictions can be made concerning the types of inclusive congregations that are most likely to exhibit loose coupling rather than take a formal organizational stance. New Institutionalism highlights the importance of the myths and norms of the environments from which organizations draw 
legitimacy. Thus, measures of various institutional environments such as stances toward politics, theology, and female leadership could be associated with whether inclusive congregations loosely couple the integration of gays and lesbians into congregational life from their formal organizational stances.

The political and theological ideologies of a congregation not only affect its response to homosexuality but also serve as a signal to the broader institutional environment (Adler 2012; Ammerman et al. 1997; Becker 1999; Whitehead 2013a, 2013b). Congregations identifying as politically and theologically liberal are most likely to officially welcome gays and lesbians compared to congregations identifying as moderate or conservative. Regarding the tendency to loosely couple however, it may be those inclusive congregations that identify as theologically and politically moderate that are most likely to accommodate gay and lesbian participation while also maintaining the traditional religious organizational stance of no formal statement of welcoming. Theologically and politically moderate congregations may find themselves inhabiting a liminal space between those congregations that can be tightly coupled and accepting of homosexuality (liberal) and those that are able to be tightly coupled and restrictive of gay and lesbian participation (conservative).

A similar state of affairs exists for those inclusive congregations that identify as interpreting the Bible as the inerrant word of God. Among all congregations, those that interpret the Bible as inerrant are more likely to be opposed to gays and lesbians participating in congregational life (Adler 2012; Whitehead 2013b). However, among inclusive congregations, those that view the Bible as inerrant should also be more likely to be loosely coupled than tightly coupled and accepting of gays and lesbians. Loose coupling would allow them to buffer practical activity from any formal organizational stance that reflects that activity. Finally, congregational 
stances toward women in leadership routinely serve as signals to the broader institutional environment (Chaves 1996, 1997) and are predictive of stances toward the inclusion of gays and lesbians into congregational life (Whitehead 2013a). Inclusive congregations that include women in leadership may be more likely to be tightly coupled and accepting of gays and lesbians than loosely coupled given the association between gender equality and inclusivity of gays and lesbians within congregations (Whitehead 2013a).

Beyond characteristics that serve as signals to the organizational environment, the actual inhabitants of the congregation are also significant. A recent and substantial addition to the New Institutionalism literature is the inhabited institutions approach. Central to this approach is the recognition of the interplay of the institutional logics that define and shape organizational and institutional environments with those inhabiting these institutions and the importance of their social interaction occurring in response to "macro-level organizational processes" (Everitt 2012, 2013; Hallett 2010; Hallett and Meanwell 2016; Hallett and Ventresca 2006a, 2006b). Inhabited institutionalism reminds us that agentic actors exist within institutions both interpreting and making sense of various institutional logics (Binder 2007; Hallett and Meanwell 2016). Thus, both clergy and congregants could play important roles in whether an inclusive congregation loosely couples its everyday practice from its formal stance, or if it maintains a tight coupling between its integration of gays and lesbians and its formal stance.

Prior research on congregations and homosexuality stress the importance of both clergy and congregants (Adler 2012; Cadge et al. 2008; Djupe and Neiheisel 2008; Djupe et al. 2006; Olson and Cadge 2002; Whitehead 2013a, 2013b). In addition to being the designated spiritual leaders of the congregation, clergy also determine if a congregation will approach the subject of homosexuality, how they will do so, and what the congregational stance will be (Cadge et al. 
2007; Cadge et al. 2008; Cadge et al. 2012; Thomas and Olson 2012). Thus, a number of clergy characteristics could play an important role. Clergy education influences a congregation's stance toward homosexuality in religious congregations (Park, Perez, and Johnson 2016; Whitehead 2013b). Educated clergy may be more likely to lead inclusive congregations that employ loose coupling because they are more aware of the issues that can arise when definitive stances are taken on the issue of homosexuality. However, it may also be that due to the liberalizing effect of education, more highly educated clergy might lead inclusive congregations that integrate gays and lesbians into congregational life and formally signal this stance (Ohlander, Batalova, and Treas 2005).

It is possible that inclusive congregations with women serving as the head clergyperson may also be more likely to exhibit loose coupling. Head clergywomen are more likely to support the participation of lesbians and gays in congregations (Whitehead 2013a) but are keenly aware of what broaching the subject might mean for their legitimacy as head clergy (Deckman, Crawford, and Olson 2008; Olson, Crawford, and Deckman 2005). Therefore, maintaining a loose coupling between who is allowed to participate in a congregation and the official stance of a congregation may benefit clergywomen. Clergy who identify as ethnic minorities might also be more likely to lead inclusive congregations that loosely couple. These clergy may be more open toward diversity in general which might include sexual diversity, but similarly aware of what a move toward formal recognition of gays and lesbians and the possibility for conflict might mean for the congregation.

Turning to the congregants who inhabit institutionalized religion, given women's greater acceptance of gays and lesbians writ large (Herek 1988) and the liberalizing effect of education (Ohlander et al. 2005), inclusive congregations with higher proportions of women and college- 
educated individuals could be less likely to loosely couple and more likely to exhibit consonance between their practical activity and formal stance. Various studies also find that younger Americans are more accepting of homosexuality (Andersen and Fetner 2008) so inclusive congregations with a greater percentage of younger congregants could also be less likely to exhibit loose coupling when compared to a tight coupling of practical activity and formal stance. In each of these cases, the clergy and the congregants - those who inhabit institutionalized religion - could influence whether inclusive congregations loosely couple their practical activity from their official organizational stance. In this sense it is an interplay between local constraints and those represented by the institutionalized norms permeating the various organizational fields from which inclusive congregations draw legitimacy.

\section{Data}

In order to investigate loose coupling in inclusive congregations I use data from the 20062007 National Congregations Study (NCS) (Chaves and Anderson 2008). The 2006-2007 NCS is a nationally representative collection of American congregations created using hyper-network sampling methods in conjunction with the 2006 General Social Survey (GSS). Respondents to the GSS who reported they attended religious services at least once a year shared the location of their religious congregation. Once the nominated congregations were located, the NCS gathered a wealth of data using a 45-60 minute interview with one key informant - usually a clergyperson - from each congregation. ${ }^{1}$ Seventy-eight percent of the interviews were with clergy, 86 percent were with staff of some kind, and the remaining 14 percent were with non-staff congregational

\footnotetext{
${ }^{1}$ Surveys using key informant methodology are not without drawbacks and these should be kept in mind when interpreting the results from this analysis (see Frenk et al. 2011; Schwadel and Dougherty 2010). However, various studies support the use of key informants generally and the strength of the NCS specifically (see Beyerlein and Chaves 2003; Chaves et al. 1999; Frenk et al. 2011).
} 
leaders. Complete data were collected from 1,506 congregations and the overall response rate for the 2006-2007 NCS was 78 percent.

A drawback of using the 2006-2007 NCS to explore this puzzle is its age. Clearly, the societal context concerning homosexuality has dramatically shifted around congregations since 2006. Therefore, the results of this analysis and their application to the present state of affairs should bear this in mind. While newer data on congregations would be ideal, the most recent wave of the NCS does not include a question that is central to the analysis as described below. Despite this, there are a couple reasons why data from this period are still quite useful. First, this was a period in US history where dramatic shifts were taking place regarding attitudes toward homosexuality. These data provide us a time-capsule of that era which can help us sharpen our understanding of organizational responses to pertinent issues dominating the social milieu. Such findings should translate to various other periods and issues and future research could explore these possibilities. Second, congregations, and organizations more broadly, are slower to adapt to changing conditions. While in the last ten years there have most likely been shifts in congregational responses to homosexuality, it may very well be that many congregations continue to exhibit similar responses - both loose and tight coupling - due to the various organizational processes described in the following analysis and to the inherent inertia of institutionalized norms across various organizational fields.

\section{Dependent Variables}

The two dependent variables measuring loose coupling are created using three separate variables from the 2006-2007 NCS. The first question asks, "Would the following types of people be permitted to be full-fledged members of your congregation: An openly gay or lesbian couple in a committed relationship?" The second is similar but asks specifically about leadership 
roles within the congregation: "Regarding leadership, if they were otherwise qualified, would the following types of people be permitted to hold all of the volunteer leadership positions open to other members: An openly gay or lesbian couple in a committed relationship?" Possible response options for each question were, "Yes," "No," and "Don't Know." In the full sample, 37.3 percent of congregations allow gay couples to become members and 17.8 percent of congregations allow gay couples to become leaders. Sixty-two percent of congregations do not allow gay couples to become members or leaders, while 17.5 percent allow gay couples to become both.

The final question used to create the dependent variables focuses on the formal stance taken by the congregation. It asks, "Some congregations have adopted written statements that officially welcome gays and lesbians. Has your congregation adopted such a statement?" Possible response options for this question were, "Yes," "No," and "Don’t Know." In the full NSC sample, 6 percent of congregations have a formal statement of welcoming. Three percent of US congregations allow for gay couples to become members and leaders and also have a formal statement of welcoming. ${ }^{2}$

For the purposes of this analysis, the analytic sample contains only those congregations that answer "Yes" to the gay couples as members and gay couples as leaders questions. These inclusive congregations integrate gays and lesbians into congregational life. Therefore, there are 523 inclusive congregations that allow gay and lesbian couples to be members and 250 inclusive congregations that allow gay and lesbian couples to be leaders.

In order to operationalize the concept of loose coupling among inclusive congregations, I cross tabulated the gay couple membership and welcome statement questions, and the gay couple leadership and welcome statement questions. Doing so created two binary variables where $1=$

\footnotetext{
${ }^{2}$ The percentages provided in the preceding two paragraphs are not displayed in the tables but are included in this section for descriptive purposes.
} 
"Loosely Coupled" and $0=$ "Tightly Coupled". Loosely Coupled inclusive congregations are those that allow gay couples in committed relationships to be members and/or leaders, but do not report having an official welcome statement. Thus, the actions of the congregation are not necessarily reflected in the official stance of the congregation. Tightly Coupled inclusive congregations are those that have an official welcome statement and allow gay couples to become members/leaders. As Table 1 shows, in our analytic sample of inclusive congregations 89.5 percent of congregations can be labeled Loosely Coupled regarding accepting committed gay couples as members while 10.5 percent are Tightly Coupled. Likewise, 82.1 percent of inclusive congregations in our analytic sample are Loosely Coupled regarding accepting committed gay couples as leaders while 17.9 percent are Tightly Coupled. Among all congregations in the US (the full NCS sample), almost 34 percent of congregations are loosely coupled regarding gay couples as members and 15 percent are loosely coupled regarding gay couples as leaders.

[Table 1 about here]

\section{Independent Variables}

Table 2 displays the descriptive statistics of the independent variables of interest. The first set concern clergy attributes. Clergy age (in years), gender (female $=1$ ), ethnicity (minority $=1$ ), and education (graduated from seminary/theological school =1) make up this category. The 2006-2007 NCS also includes various measures that the key informant provides concerning congregational demographics. Included in this analysis are the percent of the congregation that is female, the percent who earned a bachelor's degree or higher, and the percent that is under 35 years of age. The next set of measures concern congregational stances which includes whether the key informant describes the congregation as politically moderate (contrast category), 
conservative, or liberal, if the congregation would be described as theologically moderate (contrast category), conservative, or liberal, and whether the congregation considers the Bible the inerrant word of God. A final measure of congregational stance is how many leadership opportunities are available to women. This is a count variable ranging from 0 to 5 where congregations allow for women to volunteer, serve on the main governing body, teach a class by themselves with adult men in it, preach at the main worship service, and/or be the head clergyperson.

\section{Control Variables}

Additional independent variables are included in the model. Each congregation's religious tradition is also accounted for using five groups: Mainline Protestant (contrast category), Evangelical Protestant, Black Protestant, Catholic, and Other. ${ }^{3}$ The analysis also includes the percent that is white and the percent of the congregation that represents a "traditional family" defined as two married adults living together with children in the home. Finally, I control for various congregational attributes. Year founded, size (number of regularly participating adults), region of the country (South as contrast category), and size of place (urban, rural, and suburban as contrast category) are all included.

[Table 2 about here]

\section{Methods}

Due to the coding of the dependent variables, I use binary logistic regression in the multivariate analyses. The data are weighted using the NCS WTA3CNGD variable. This weights the data from the average congregation's perspective. This is the ideal weight for an organizational analysis of congregations. To ensure multicollinearity was not adversely affecting

\footnotetext{
${ }^{3}$ Due to the small number of Jewish synagogues in the 2006-2007 NCS, they are included in the Other category alongside various other non-Christian groups.
} 
the models, I investigated the correlations between the independent and dependent variables, as well as between all of the independent variables (correlation table not shown here but is available upon request). For the independent variables with high correlations I ran a host of ancillary models (available upon request). The results reported below did not change in any substantive manner across all of these models. As a final check I then ran the full models using ordinary least squares regression in order to inspect the variance inflation factor scores (VIF) (Allison 2001; Stroope, Draper, and Whitehead 2013; Whitehead and Perry 2015). Across both full models the VIF scores for all variables are below the standard of 10 that indicates multicollinearity problems (Meyers, Gamst, and Guarino 2006). Finally, in order to assess substantive significance alongside statistical significance, the coefficients displayed in Table 3 are standardized regression coefficients $\left[B_{y x}^{*}=b_{y x}\left(s_{x} / s_{y}\right)\right]\left(\right.$ Pampel 2000). ${ }^{4}$

\section{Results}

Table 3 displays the results of the logistic regression models predicting the likelihood of inclusive congregations loosely coupling their official stance from integrating gays and lesbians as members (model 1) and as leaders (model 2). Looking first at clergy attributes, for both allowing gay couples to become members $(\beta=0.26)$ and allowing gay couples to become leaders $(\beta=0.47)$ older clergy are more likely to lead inclusive congregations that loosely couple. For each additional year in age, the odds that clergy lead an inclusive congregation that loosely couples increase between five and 10 percent. The only other clergy attribute that is significantly associated with congregational loose coupling is gender. Clergywomen are less likely to lead a loosely coupled congregation $(\beta=-0.07)$ and more likely to lead a tightly coupled inclusive

\footnotetext{
${ }^{4}$ I follow Pampel's (2000) assumption that the standard deviation of logit $(\mathrm{y})=1.8138$.
} 
congregation that officially reflects their acceptance of gays and lesbians in its organizational stance.

[Table 3 about here]

Only one measure of congregational demographics plays a role in predicting which congregations loosely couple. Inclusive congregations with higher percentages of women are less likely $(\beta=-0.42)$ to loosely couple and thus more likely to take an official congregational stance of welcoming to reflect their acceptance of gay couples as leaders. Comparing standardized coefficients, this is one of the strongest predictors in the model.

A number of congregational stances significantly predict loose coupling. Compared to politically moderate inclusive congregations, those that identify as politically liberal are much less likely to loosely couple official congregational stances from allowing gay members ( $\beta=-$ 0.31) or gay leaders $(\beta=-0.45)$. Politically liberal inclusive congregations are more likely to exhibit tight coupling between their practical activity and their formal organizational stance. Politically conservative inclusive congregations, compared to politically moderate inclusive congregations, are also less likely $(\beta=-0.36)$ to exhibit loose coupling concerning allowing gay couples to serve as leaders. In both cases, politically moderate inclusive congregations are more likely to exhibit loose coupling. Theologically liberal inclusive congregations, when compared to theologically moderate inclusive congregations, are less likely $(\beta=-0.42)$ to report loose coupling regarding allowing gay couples to serve as leaders. Finally, inclusive congregations that report interpreting the Bible as inerrant are more likely $(\beta=0.27)$ to loosely couple their integration of gay couples as members from their official organizational stance.

Among the various control variables, the only significant association is between congregation size and loose coupling as it relates to inclusive congregations allowing gay 
leaders. As the size of a congregation increases, the likelihood $(\beta=-0.27)$ of loose coupling decreases. Larger congregations are therefore more likely to be tightly coupled and pair an official welcome statement with their acceptance of gay couples as leaders.

\section{Discussion}

Using a nationally representative sample of US congregations, this analysis examines the particular organizational responses taken by inclusive religious congregations toward gays and lesbians. Beyond predicting whether congregations merely accept or reject gay and lesbian members and leaders (Adler 2012; Whitehead 2013a), these findings focus on the liminal space between accepting gays and lesbians into congregational life and taking a formal organizational step to officially welcome sexual minorities. It takes into account not only the day-to-day activities of congregations, but the formal organizational stances of those congregations. Loose coupling is an important organizational adaptation, especially concerning homosexuality, because it allows an inclusive congregation to adapt to a changing environment without disturbing the organization as a whole. Gays and lesbians are integrated into congregational life but the organization does not have to make a formal declaration which could lead to both internal and external conflict. Various congregational characteristics are found to influence whether inclusive congregations loosely couple their day-to-day activities from their official organizational stances, as predicted following the new institutionalism and the inhabited institutions approaches.

Religious organizations seek legitimacy from their institutional environment and it appears that politics is one field through which they do so. Interestingly, the political culture of inclusive congregations plays a more important role in predicting whether it will employ loose coupling than does its theological culture. Moreover, politically moderate inclusive 
congregations are much more likely to utilize loose coupling than politically liberal inclusive congregations who are much more likely to be tightly coupled. This is a consistent finding for both the membership and leadership questions. Politically moderate inclusive congregations appear to inhabit a liminal space between full acceptance and committed opposition and are most likely to loosely couple official stances from practical day-to-day activities in an institutional environment undergoing dramatic shifts. This finding also suggests that congregations are responsive to the myths and norms of various organizational fields. Identifying with a particular political ideology is significantly related to how an inclusive congregation signals its official organizational stance toward an issue that is highly politicized. Inclusive congregations identifying as politically liberal are seeking legitimacy from this particular organizational field by adhering to its norms.

Local theological culture within inclusive congregations appears to be only partially associated with whether a congregation is loosely or tightly coupled. In one model we find that compared to theologically moderate inclusive congregations, theologically liberal inclusive congregations are more likely to tightly couple their integration of gay and lesbian couples as leaders with an official organizational statement of welcoming. Beyond this significant association, theologically moderate inclusive congregations do not appear to be more or less likely to loosely couple compared to theologically liberal or conservative congregations. An additional measure of local theological culture is significant regarding loose coupling within inclusive congregations. Prior research shows congregations that consider the Bible inerrant are more opposed to homosexuality (Adler 2012). However, when focused on loose coupling among inclusive congregations we see the story is somewhat more complicated. Regarding gay and lesbian membership, inclusive congregations who interpret the Bible as inerrant are actually 
more likely to maintain loose coupling than to be tightly coupled. The congregations that interpret the Bible as inerrant are adapting to the perhaps competing demands of their local context - a need to integrate gay and lesbian couples into congregational life - and the organizational environment from which they draw legitimacy. They do this by loosely coupling their practical activity from their official organizational stance.

The inhabited institutions approach also illuminates which inclusive congregations are most likely to loosely couple. In line with past literature on the importance of clergy concerning congregational stances toward homosexuality (Cadge et al. 2012; Djupe and Neiheisel 2008; Olson and Cadge 2002), we see again that clergy attributes are associated with whether or not an inclusive congregation maintains loose coupling. Consistently, older clergy are likely to lead loosely coupled congregations. Conversely, clergywomen are more likely to lead tightly coupled inclusive congregations. Prior research demonstrates that clergy with minority statuses (gender, race/ethnicity) recognize their role as lead clergy as a political and theological statement in and of itself and are therefore more hesitant to use additional social capital to broach politically and theologically difficult topics like homosexuality (Deckman et al. 2008; Olson et al. 2005). In this analysis, though, it appears that clergywomen are more likely to lead inclusive congregations that take an official organizational stance that reflects their practical activity of integrating gays and lesbians in to congregational life. This is in line with prior research on homosexuality and gender within congregations. As the literature on inequality regimes within organizations predicts, organizational responses to the experiences of historically marginalized groups are inextricably linked (Acker 2006; Britton and Logan 2008; Whitehead 2013a).

The importance of the clergy in predicting loose coupling supports the inhabited institutions literature. As the inhabited institutions approach instructs, agentic actors existing 
within institutional structures are constantly interacting with and responding to various broader environmental norms. However, there is relatively little evidence of the influence of congregants on the propensity of inclusive congregations to loosely couple. The percent of the congregation that are women is significantly associated with its likelihood of loose coupling in one of the models. Inclusive congregations with more women are more likely to formally signal their openness to gay and lesbian couples alongside their acceptance of these groups as leaders. Taken together, the significant clergy attributes and congregational demographics measures provide partial empirical support for the inhabited institutions approach.

As with all studies, there are limitations that deserve mention. First, this data is crosssectional and so any suggestion of causality is unwarranted. It could be that congregational stances - like being loosely coupled - push certain types of congregants or clergy away or pull particular types in. The associations presented in Table 3 should be interpreted with this in mind. However, the host of ethnographic studies in the new institutionalism literature and on congregations suggest that in many cases the direction of influence in the present interpretation of the findings is warranted. Second, the data used here is from 2006-2007. As discussed in the Data section above, there could be significant changes within inclusive congregations in the last decade concerning loose coupling and the integration of gays and lesbians. Regrettably, the most recent wave of the NCS collected in 2012 does not contain the welcome statement question central to the analyses presented here. It is also worth noting that while the data are not from the past few years, they are from a period where an incredible amount of change was taking place in the broader population regarding attitudes toward gays and lesbians. At the very least, these data provide a useful snapshot of that moment in time and allow us to test organizational theory in a rapidly evolving context. 


\section{Conclusion}

In essence, congregations are organizations intent on survival. In order to survive, they like any other organization - must draw upon various institutional norms to establish their legitimacy (Greenwood and Hinings 1996; Meyer and Rowan 1977; Scott et al. 1993).

Congregations are also interpenetrated with agentic actors who constantly interact with and shape the implementation of those norms (Everitt 2012, 2013; Hallett 2010; Hallett and Meanwell 2016; Hallett and Ventresca 2006a, 2006b). Regarding homosexuality, some inclusive congregations appear to employ loose coupling where their formal organizational stance does not necessarily represent the realities of day-to-day organizational activities. For a significant minority of congregations, this means integrating gays and lesbians into organizational life while simultaneously foregoing any formal signal to the institutional environment that gays and lesbians are officially welcome. Loose coupling makes congregations more sensitive to changes within the environment and ultimately more capable of responding to those changes (Hallett and Ventresca 2006b; Orton and Weick 1990; Weick 1976). Using a nationally representative sample of congregations, this study finds that there are two important categories of predictors of whether an inclusive congregation that integrates gays and lesbians into congregational life will loosely couple. The first are those basic signals to the institutional environment like local political and theological cultures. The second concern those who inhabit institutionalized religion and interact within the organization. Clergy play an important role in the organization of congregational life and its stance toward gays and lesbians.

Future research on congregations would do well to continue to utilize the theoretical perspective of new institutionalism and inhabited institutions. Further ethnographic work focusing specifically on the ways in which inclusive congregations loosely couple their formal 
organizational stances from their lived realities is necessary. The organizational concept of loose coupling provides a number of interesting possibilities. This could include additional studies of homosexuality but can also expand to other areas like congregational responses to the worldwide refugee crisis, gender inequality, various political actions, and social and community activism. Whatever the focus, it is vital to recognize that congregations are adaptable and organizational innovation is constantly happening (Bruce and Packard 2016). The current study aligns with Bruce and Packard's (2016:171) call to think more "about the conditions that give rise to particular kinds of [organizational] behavior, or increase the likelihood of particular kinds of innovation." Knowing which types of congregations are mostly likely to loosely couple helps us see the conditions within which organizational innovation - with an eye toward organization survival - can take place. 


\section{References}

Acker, Joan. 2006. "Inequality Regimes: Gender, Class, and Race in Organizations." Gender and Society 20(4):441-64.

Adler, G. 2012. "An opening in the congregational closet? Boundary-bridging culture and membership privileges for gays and lesbians in Christian religious congregations." Social Problems 59(2):177-206.

Allison, Paul. 2001. "Logistic regression using the SAS system: Theory and application. New York, NY: John Wiley.

Ammerman, Nancy Tatom, Arthur E. Farnsley, et al. 1997. Congregation and community. New Brunswick, NJ: Rutgers University Press.

Andersen, Robert, and Tina Fetner. 2008. "Cohort differences in tolerance of homosexuality: Attitudinal change in Canada and the United States, 1981-2000." Public Opinion Quarterly 72(2): 311-330.

Basu, Onker N., Mark W. Dirsmith, and Parveen P. Gupta. 1999. "The Coupling of the Symbolic and the Technical in an Institutionalized Context: The Negotiated Order of the GAO's Audit Reporting Process." American Sociological Review 64:506-526.

Becker, Penny Edgell. 1999. Congregations in conflict: Cultural models of local religious life. Cambridge: Cambridge University Press.

Beyerlein, Kraig, and Mark Chaves. 2003. "The Political activities of religious congregations in the United States.” Journal for the Scientific Study of Religion 42: 229-246.

Binder, Amy J. 2007. "For Love and Money: Organizations' Creative Responses to Multiple Environmental Logics." Theory and Society 36(6):547-71.

Britton, Dana M. and Laura Logan. 2008. "Gendered Organizations: Progress and Prospects." Sociology Compass 2(1):107-21.

Bruce, Tricia C. and Josh Packard. 2016. “Organizational Innovation.” In David Yamane (ed.) Handbook of Religion and Society, pp. 155-175. Switzerland: Springer International Publishing.

Cadge, Wendy, Heather Day, and Christopher Wildeman. 2007. "Bridging the DenominationCongregation Divide: Evangelical Lutheran Church in America Congregations Respond to Homosexuality." Review of Religious Research 48(3):245-259.

Cadge, Wendy, Jennifer Girouard, Laura R. Olson, and Madison Lylerohr. 2012. "Uncertainty in clergy's perspectives on homosexuality: A research note." Review of Religious Research 54(3):371-387. 
Cadge, Wendy, Laura R. Olson, and Christopher Wildeman. 2008. "How Denominational Resources Influence Debate about Homosexuality in Mainline Protestant Congregations.” Sociology of Religion 69(2):187-207.

Chaves, Mark. 1996. "Ordaining Women: The Diffusion of an Organizational Innovation.” The American Journal of Sociology 101(4):840-873.

------ 1997. Ordaining Women: Culture and Conflict in Religious Organizations. Cambridge, MA: Harvard University Press.

Chaves, Mark and Shawna Anderson. 2008. National Congregations Study. Cumulative data file and codebook. Durham, North Carolina: Duke University, Department of Sociology.

Chaves, Mark, Mary Ellen Konieczny, Kraig Beyerlein, and Emily Barman. 1999. "The national congregations study: Background, methods, and selected results." Journal for the Scientific Study of Religion 38: 458-476.

Clark, Rob. 2010. "Technical and Institutional States: Loose Coupling in the Human Rights Sector of World Polity.” The Sociological Quarterly 51(1):65-95.

Deckman, Melissa, Sue E. S. Crawford, and Laura R. Olson. 2008. "The politics of gay rights and the gender gap: A perspective on the clergy." Politics and Religion 1(3):384-410.

DiMaggio, Paul J. and Walter W. Powell. 1983. “The Iron Cage Revisited: Institutional Isomorphism and collective Rationality in Organization Fields." American Sociological Review 48:147-160.

Djupe, Paul A., Laura R. Olson, and Christopher P. Gilbert. 2006. "Whether to Adopt Statements on Homosexuality in Two Denominations: A Research Note." Journal for the Scientific Study of Religion 45(4):609-621.

Djupe, Paul A. and Jacob R. Neiheisel. 2008. "Deliberation on Gay Rights and Homosexuality in Churches." Polity 40:411-35.

Everitt, Judson G. 2012. "Teacher Careers and Inhabited Institutions: Sense-Making and Arsenals of Teaching Practice in Educational Institutions." Symbolic Interaction 35(2):203-220.

Everitt, Judson G. 2013. "Inhabitants Moving In: Prospective Sense-Making and the Reproduction of Inhabited Institutions in Teacher Education." Symbolic Interaction 36(2):177-196.

Frenk, Steven M., Shawna L. Anderson, Mark Chaves, and Nancy Martin. 2011. "Assessing the validity of key informant reports about congregations' social composition." Sociology of Religion 72(1): 78-90. 
Greenwood, Royston and C.R. Hinings. 1996. "Understanding Radical Organizational Change: Bringing Together the Old and the New Institutionalism." Academy of Management Review 21(4):1022-1054.

Hallett, Tim. 2010. "The Myth Incarnate: Recoupling Processes, Turmoil, and Inhabited Institutions in an Urban Elementary School." American Sociological Review 75(1):52-74.

Hallett, Tim and Emily Meanwell. 2016. "Accountability as an Inhabited Institution: Contested Meanings and the Symbolic Politics of Reform.” Symbolic Interaction 39(3):374-396.

Hallett, Tim and Marc J. Ventresca. 2006a. "Inhabited Institutions: Social Interactions and Organizational Forms in Gouldner's Patterns of Industrial Bureaucracy." Theory and Society 35:213-236.

-----. 2006b. "How Institutions Form: Loose Coupling as Mechanism in Gouldner's Patterns of Industrial Bureaucracy.” American Behavioral Scientist 49(7):908-924.

Hartman, Keith. 1996. Congregations in conflict: The battle over homosexuality. New Brunswick, NJ: Rutgers University Press.

Herek, Gregory M. 1988. Heterosexuals' attitudes toward lesbians and gay men: Correlates and gender differences. Journal of Sex Research 25(4):451-77.

Meyer, John. 1983. "On the celebration of rationality." Accounting, Organizations and Society 8:235-240.

Meyer, John W. and Brian Rowan. 1977. "Institutionalized Organizations: Formal Structure as Myth and Ceremony." American Journal of Sociology 83(2):340-362.

Meyers, Lawrence S., Glenn Gamst, and A. J. Guarino. 2006. Applied multivariate research: Design and interpretation. Thousand Oaks, CA: Sage Publication.

Moon, Dawne. 2004. God, sex, and politics: Homosexuality and everyday theologies. Chicago, IL: The University of Chicago Press.

Ohlander, Julianne, Jeanne Batalova, and Judith Treas. 2005. "Explaining education influences on attitudes toward homosexual relations." Social Science Research 34(4):781-99.

Olson, Laura R. and Wendy Cadge. 2002. "Talking about Homosexuality: The Views of Mainline Protestant Clergy.” Journal for the Scientific Study of Religion 41(1):153-167.

Olson, Laura R., Sue E. S. Crawford, and Melissa M. Deckman. 2005. Women with a mission: Religion, gender, and the politics of women clergy. Tuscaloosa: University of Alabama Press.

Pampel, Fred C. 2000. Logistic regression: A primer. Thousand Oaks, CA: Sage. 
Park, John, Pamela R. Perez, and Johnny Ramírez-Johnson. 2016. "The Impact of Education on Views of Homosexuality in the Senior Clergy of Hidalgo County, Texas." Journal of Religion and Health 55:778-786.

Orton, J. Douglas and Karl E. Weick. 1990. "Loosely Coupled Systems: A Reconceptualization." Academy of Management Review 15(2):203-223.

Scheitle, Christopher P., Stephen M. Merino, and Andrew Moore. 2010. “On the varying meaning of "open and affirming." Journal of Homosexuality 57(10):1223-36.

Schwadel, Philip, and Kevin D. Dougherty. 2010. "Assessing key informant methodology in congregational research.” Review of Religious Research 51: 366-379.

Scott, W. Richard and John W. Meyer (eds.). 1994. Institutional Environments and Organizations: Structural Complexity and Individualism. Thousand Oaks, CA: Sage.

Stroope, Samuel, Scott Draper, and Andrew L. Whitehead. 2013. "Images of a loving God and sense of meaning in life." Social Indicators Research 111(1):25-44.

Swiss, Liam. 2009. "Decoupling Values from Action: An Event-History Analysis of the Election of Women to Parliament in the Developing World, 1945-1990." International Journal of Comparative Sociology 50(1):69-95.

Thomas, Jeremy N., and Daniel V.A. Olson. 2012. "Beyond the culture war: Managing sexual relationships inside a congregation of gay Evangelicals." Review of Religious Research 54(3):349-370.

Weick, Karl E. 1976. "Educational Organizations as Loosely Coupled Systems." Administrative Science Quarterly 21(1):1-19.

Whitehead, Andrew L. 2013a. "Gendered organizations and inequality regimes: Gender, homosexuality, and inequality within religious congregations." Journal for the Scientific Study of Religion 52(3):476-493.

Whitehead, Andrew L. 2013b. "Religious organizations and homosexuality: The acceptance of gays and lesbians in American congregations." Review of Religious Research 55(2):297317.

Whitehead, Andrew L. and Samuel L. Perry. 2015. A more perfect union? Christian nationalism and support for same-sex unions. Sociological Perspectives 58(3): 422-440.

Wilcox, W. Bradford, Mark Chaves, and David Franz. 2004. "Focused on the Family? Religious Traditions, Family Discourse, and Pastoral Practice." Journal for the Scientific Study of Religion 43(4):491-504. 
Young, Viki M. 2006. “Teachers' Use of Data: Loose Coupling, Agenda Setting, and Team Norms." American Journal of Education 112:521-548.

Yang, Song and Lu Zheng. 2011. "The Paradox of De-coupling: A Study of Flexible Work Program and Workers' Productivity.” Social Science Research 
Table 1: Loose Coupling among Inclusive Congregations and All US Congregations

\begin{tabular}{lcc}
\hline & $\begin{array}{c}\% \text { of } \\
\text { Congregations - } \\
\text { Analytic Sample }\end{array}$ & $\begin{array}{c}\text { \% of } \\
\text { Congregations - } \\
\text { Full Sample }\end{array}$ \\
\hline $\begin{array}{l}\text { Loosely Coupled - Allow Gay Members/No Welcome } \\
\begin{array}{l}\text { Statement } \\
\text { Tightly Coupled }\end{array}\end{array}$ & 89.5 & 33.6 \\
$\begin{array}{l}\text { Loosely Coupled - Allow Gay Leaders/No Welcome } \\
\begin{array}{l}\text { Statement } \\
\text { Tightly Coupled }\end{array}\end{array}$ & 10.5 & 4.0 \\
\hline
\end{tabular}

Source: 2006-2007 NCS (weighted data)

Note: Analytic sample consists only of inclusive congregations that allow gays and lesbians to be members and/or leaders 
Table 2: Descriptive Statistics for Analytic and Full Sample - Independent Variables

\begin{tabular}{|c|c|c|c|c|}
\hline & \multicolumn{2}{|c|}{ Analytic Sample } & \multicolumn{2}{|c|}{ Full Sample } \\
\hline & Mean or \% & SD & Mean or \% & SD \\
\hline \multicolumn{5}{|l|}{ Clergy Attributes } \\
\hline Age & 55.7 & 10.3 & 53.3 & 11.9 \\
\hline Female & 9.7 & --- & 7.9 & --- \\
\hline Ethnic minority & 35.3 & --- & 30.8 & --- \\
\hline Education & 71.1 & --- & 61.9 & --- \\
\hline \multicolumn{5}{|l|}{ Congregational Demographics } \\
\hline$\%$ Female & 62.9 & 11.8 & 63.0 & 14.1 \\
\hline$\%$ w/ Bachelors & 33.0 & 23.9 & 27.8 & 25.6 \\
\hline$\%$ Under 35 years old & 22.2 & 15.2 & 25.2 & 18.1 \\
\hline$\%$ White & 57.33 & 40.3 & 65.5 & 42.6 \\
\hline$\%$ Traditional Family & 34.8 & 25.2 & 38.3 & 28.8 \\
\hline \multicolumn{5}{|l|}{ Congregational Stances } \\
\hline Politically Moderate & 47.0 & --- & 34.6 & --- \\
\hline Politically Conservative & 42.2 & --- & 58.0 & --- \\
\hline Politically Liberal & 10.7 & --- & 7.4 & --- \\
\hline Theologically Moderate & 41.3 & --- & 29.5 & --- \\
\hline Theologically Conservative & 46.2 & --- & 62.8 & --- \\
\hline Theologically Liberal & 12.6 & --- & 7.7 & --- \\
\hline Inerrant Bible & 66.7 & --- & 82.5 & --- \\
\hline Women leadership opportunities & 4.0 & 1.2 & 3.5 & 1.63 \\
\hline \multicolumn{5}{|l|}{ Religious Tradition } \\
\hline Mainline Protestant & 31.7 & --- & 18.8 & --- \\
\hline Evangelical Protestant & 17.0 & --- & 44.8 & --- \\
\hline Catholic & 13.2 & --- & 6.0 & --- \\
\hline Black Protestant & 29.9 & --- & 23.4 & --- \\
\hline Other & 5.1 & --- & 5.6 & --- \\
\hline \multicolumn{5}{|l|}{ Congregational Attributes } \\
\hline Year founded & 1917 & 53.2 & 1932 & 53.4 \\
\hline Size & 156.4 & 318.6 & 124.1 & 293.7 \\
\hline South & 46.7 & --- & 47.7 & --- \\
\hline North East/Mid-Atlantic & 18.8 & --- & 12.9 & --- \\
\hline East North Central/West North Central & 19.3 & --- & 25.0 & --- \\
\hline Mountain/Pacific & 15.2 & --- & 14.4 & --- \\
\hline Suburban & 24.6 & --- & 23.3 & --- \\
\hline Urban & 48.4 & --- & 44.1 & --- \\
\hline Rural & 27.0 & --- & 32.6 & --- \\
\hline
\end{tabular}

Source: 2006-2007 NCS (weighted data)

Note: Analytic sample consists only of inclusive congregations that allow gays and lesbians to be members and/or leaders 
Table 3: Logistic Regression of Inclusive Congregations and Loose Coupling

\begin{tabular}{|c|c|c|c|c|}
\hline & \multicolumn{2}{|c|}{$\begin{array}{l}\text { Loosely Coupled - Allow Gay } \\
\text { Members/No Welcome } \\
\text { Statement vs. Tightly Coupled - } \\
\text { Accepting Gay Members }\end{array}$} & \multicolumn{2}{|c|}{$\begin{array}{l}\text { Loosely Coupled - Allow Gay } \\
\text { Leaders/No Welcome Statement } \\
\text { vs. Tightly Coupled - Accepting } \\
\text { Gay Leaders }\end{array}$} \\
\hline & $\beta$ & OR & $\beta$ & OR \\
\hline \multicolumn{5}{|l|}{ Clergy Attributes } \\
\hline Age & $0.26^{*}$ & 1.05 & $0.47 *$ & 1.09 \\
\hline Female & $-0.07 \dagger$ & 0.38 & -0.18 & --- \\
\hline Ethnic minority & -0.22 & --- & -0.24 & --- \\
\hline Education & 0.16 & --- & 0.25 & --- \\
\hline \multicolumn{5}{|l|}{ Congregational Demographics } \\
\hline$\%$ Female & -0.19 & --- & $-0.42 \dagger$ & 0.93 \\
\hline$\%$ w/ Bachelors & 0.05 & --- & -0.01 & --- \\
\hline$\%$ Under 35 years old & -0.11 & --- & -0.20 & --- \\
\hline$\%$ White & -0.27 & --- & -0.18 & --- \\
\hline$\%$ Traditional Family & 0.13 & --- & -0.04 & --- \\
\hline \multicolumn{5}{|l|}{ Congregational Stances } \\
\hline Politically Conservative & -0.22 & --- & $-0.36 \dagger$ & 0.19 \\
\hline Politically Liberal & $-0.31 * *$ & 0.17 & $-0.45^{*}$ & 0.12 \\
\hline Theologically Conservative & -0.08 & --- & -0.26 & --- \\
\hline Theologically Liberal & -0.10 & --- & $-0.42 \dagger$ & 0.15 \\
\hline Inerrant Bible & $0.27 \dagger$ & 3.16 & 0.31 & --- \\
\hline $\begin{array}{l}\text { Women leadership } \\
\text { opportunities }\end{array}$ & -0.38 & --- & -0.39 & --- \\
\hline \multicolumn{5}{|l|}{ Religious Tradition } \\
\hline Evangelical Protestant & -0.09 & --- & -0.13 & --- \\
\hline Catholic & 0.07 & --- & 0.34 & --- \\
\hline Black Protestant & 0.11 & --- & 0.18 & --- \\
\hline Other & 0.01 & --- & 0.02 & --- \\
\hline \multicolumn{5}{|l|}{ Congregational Attributes } \\
\hline Year founded & 0.15 & --- & 0.31 & --- \\
\hline Size & -0.14 & --- & $-0.27 \dagger$ & 0.99 \\
\hline North East/Mid-Atlantic & 0.06 & --- & 0.20 & --- \\
\hline $\begin{array}{l}\text { East North Central/West North } \\
\text { Central }\end{array}$ & -0.00 & --- & 0.26 & --- \\
\hline Mountain/Pacific & 0.04 & --- & 0.16 & --- \\
\hline Urban & -0.17 & --- & -0.11 & --- \\
\hline Rural & -0.01 & --- & 0.28 & --- \\
\hline $\mathrm{N}$ & 523 & & 250 & \\
\hline PRE & 0.264 & & 0.393 & \\
\hline
\end{tabular}

Source: 2006-2007 National Congregations Study (Weighted Data)

$\dagger \mathrm{p}<0.10 ; * \mathrm{p}<0.05 ; * * \mathrm{p}<0.01 ; * * * \mathrm{p}<0.001$

Contrast Categories: South, Suburban, Mainline Protestant, Politically Moderate, Theologically Moderate PRE $=$ Proportional Reduction in Error (Likelihood Ratio/-2 Log Likelihood) 